\title{
The relationship between Us/Them dialectics and agonism in Polish context
}

\section{KEYWORDS}

agonism, antagonism, deliberation, democracy, dialectics, discourse, ethics, phantasm, fundamentalism, hegemony, history, ideology, otherness, conflict, culture, narration, hatred, pluralism, politics, difference

\begin{abstract}
Jastrząb Patryk, The relationship between We/They dialectics and agonism in Polish context. Culture - Society Education no 2(16) 2019, Poznań 2019, pp. 245-263, Adam Mickiewicz University Press. ISSN 2300-0422. DOI 10.14746/kse.2019.16.16.

I focused on the unconstrained but established in the theory reflection on We/They dialectics, which was analysed for its antagonistic foundation as being understood in the Polish context. However, I did not only concentrate on presenting the socio-political perspective of this subject as I have adopted a more contemplative, philosophical approach. Therefore political reality was only a pretext for me to tell a reader about a much more fundamental conflict concerning our values and freedom. I concluded the consideration with stating the fact of the possibility of existence of agonistic diversity among democratic variety.
\end{abstract}

\section{Dialectical thinking and the figure of the Other}

The starting point for my reflections is the assumption that the basis for a majority of conflicts in our country is the perception of minorities in terms of a threat. The axis of national disputes is usually determined by the antagonistic dialectic We/Them. Its essence is the permanent pursuit of an "enemy". It is always a stranger, but not necessarily an external threat for us. The enemy may as well exist already "inside". On the other hand, the phantasmatic (or non-phantasmat-

\footnotetext{
* ORCID https://orcid.org/0000-0001-8674-7663.
} 
ic) otherness that always accompanies the enemy is something common. ${ }^{1}$ The manner in which we evaluate the enemy is determined by paralogical thinking that was analysed by Friedrich Nietzsche and described very skilfully by Gilles Deleuze in his book devoted to the German philosopher: "You are bad, and I am the opposite of who you are, therefore I am good." (see Deleuze, 2012: 156). Using this kind of absurd reasoning as a basis is usually connected with resentment and is axiologically destructive, because it undermines the most important value: the value of the human being as a human being. Giving in to such thinking, one must first "conceive a non-ego, then oppose himself to this non-ego and finally posit himself as self." (see Deleuze, 2012: 154). Irrespective of whom such reasoning concerns, it is destructive for everyone and certainly has nothing to do with the idea of democracy, which allows for contradictions and differences, because it has to.

Such perception of otherness is determined by the cultural code that is inscribed in our collective identity as Poles. Of course, this code is not representative of everyone. However, there are people for whom the existence of the "homeland" is conditional upon some more or less concretised form of "foreign land." Because of its mental and emotional character, the awareness of the functioning of such "foreign land" strengthens the antagonistic vision of reality and legitimises the dialectical division of the community between "insiders," who belong to it, and "outsiders", who are excluded from it. Our attitude to them, the way we treat them and the way we live with them is determined by the form of the axiological attitude that consists of certain values and evaluations accompanying them. However, the choice of what we consider to be right in our encounter with otherness is not as obvious as many would like to believe. Its ambiguousness, therefore, must determine the need to answer a number of questions, the most important of which should refer to whether we regard ourselves as better, or simply as different. Depending on what seems cognitively right and morally justified to us, we can ascertain the things in which our humanity consists (Wójcicki, 2015).

\footnotetext{
${ }^{1}$ Here I mean not only otherness manifesting itself in a non-Polish descent, but each otherness that becomes apparent in confrontation with what the social majority represents.

${ }^{2}$ Here, we can refer to Ernest Gellner, who formulated a very interesting though rather radical idea that nationalism creates the nation, not the other way round. Following this argument, we would have to acknowledge the claim put forward by nationalism as a political doctrine. And the essence of this request would be the "requirement" of identity between political and ethnic borders. You can read more about this in his book Nations and Nationalism.
} 
The pursuit of individual answers to these questions is also important because, as Professor Joanna Tokarska-Bakir aptly observes, otherness

is not an island built in opposition to nativeness. Each of us is a stranger in a sense, and each carries a kind of his own unique otherness within himself. The belief that this is not so and all of us are identical is a harmful prejudice that falsifies the social reality. (Tokarska-Bakir, 2014)

Thus, some individual model of life with which everyone without exception could identify is a myth. We are not the same; moreover, each of us has his own moral world. The only common thing can be the denominator that connects all of us: Christianity as an ethical foundation of our cultural circle. ${ }^{3}$ Accepting the veracity of this statement, we would also have to agree with the axiomatic imperative of the love of our neighbour. In view of this, all forms of hostility towards what is other could be evaluated in terms of ethical deformation that is contrasted with a superior moral norm.

\section{Anthropological sources of antagonism}

Thus, the question what we would have to answer is where our hatred comes from at all? Why do we hate by dividing and refuse rights and freedom to persons who are entitled them as much as we are?

When looking for necessary answers, it would be good to start with an analysis of what Vaclav Havel called the "anatomy of hatred." (see Havel, 2011) During his speech delivered in Oslo in 1990, the Czech constructed very aptly the genealogy of hatred, the sources of which he seeks in the unsatisfied "thirst for the absolute". In his conception, Havel presents the view that we hate because we are bothered by the void resulting from unfulfilled dreams and needs and huge ambitions that actually cannot be finalised. The inability to come to terms with one's life must, therefore, result in a sense of harm and greatly exaggerated external injustice. However, the hating person never puts the blame for his situation on himself, but on Others, who become the object of his hatred and a personification of the evil surrounding him. It is them who prevent him from personal

\footnotetext{
${ }^{3}$ Krzysztof Pomian described this brilliantly in his text Europe as a pluralistic community of values [Europa jako pluralistyczna wspólnota wartości]. He states that "irrespective of whether you are a non-believer or a believer and what faith you profess, you are an inheritor of Christian heritage per force, to the extent that you are a European" (Pomian, 2004: 280).
} 
fulfilment and the takeover of the "divine throne," which he treats as a symbol of happiness and a phantasm of something that is unachievable, but assumes the status of the ultimate desire. To strive for it blindly and at any price - this is the existential sense and reason for which we have, deeply believing in the rationality of our actions and the rightness of external expectations, the idiom of which is the requirement of love and obedience that does not tolerate any objection. Failing to achieve his goal and not being situated in the "centre of the universe," the hating person feels ignored and humiliated, which only exacerbates his hatred. It is worth noting here that the most important thing for the hating person is animosity itself, not its object; the latter is only a materialised object of hate a destructive feeling addressed not to a single individual, but to the world in general - and, which is very significant, has its substitutes.

We must stress with full force that the vision of hatred presented here forms a kind of anthropological aberration. It bears the characteristics of relational sadism and mental masochism, because it excludes the acceptance of fate, which, irrespective of the hating person's "guilt," is perceived as constantly unfavourable and contesting his personal value. It must be added that this value is exceptional, but most often conceived only by the hating person himself and not fixed in the objective reality. The hating individual is characterised by narcissism and egocentrism that sets him on the side of God, whom he wants to equal. He is concerned about this not only because it is a determinant of success, i.e., a guarantee of recognition and due respect towards the uniqueness of the Chosen One. It is also an element common for all hating people: the fulfilment of hate that is no longer individual, but collective - a collective emotion establishing a sense of community. Its essence is to become liberated from the limitations of loneliness and to feel the same injustice and suffering as others do. The entire project of hatred is also common, identifying the source of failure and sentencing it to condemnation by the "affected" community. With such support, physical or even symbolic aggression appears to be justified by the authority of the group. Besides, it is not the only factor legalising the hating person's violence. Such a person very often seeks a historical foundation for his imagination. He refers to the past by looking for memories of real injustice, and current animosities constitute a reply to it.

Havel proves that this is the most dangerous form of hatred. It is difficult to oppose such hatred if we do not understand it and do find its seeds in ourselves. The last thing is particularly important because, as Leszek Kołakowski aptly noticed: "there is a root of evil in us and we do not have the strength to tear it out of our existence completely, but there is also a seed of good that we can fertilise." (Kołakowski, 2005: 108). 
Thus, we must do everything to have more good and less evil in ourselves; the latter is a negative quality that sticks in each of us, regardless of our internal construction. It is simply an immanent element of human existence and the human being itself becoming a victim of its own passions. It would have to be associated primarily with egoism, or the "law of perspective." (see Nietzsche, 2008: 153) something definitely individual, which determines and legalises the externalised manifestation of one's own desires and lusts. This has already been described by Plato in The Republic and by Thomas Hobbes in Leviathan, and subsequently also by utilitarianists. All of them assumed that our own interest determines who we are and what we do. Hobbes even thought that the human being is not a social being, contrary to what Aristotle believed, and as if in opposition to this, he proposed a much more pessimistic assumption (see Czarnecki, 2011). He thought that our life cannot do without asociality - an individual orientation that emphasises the autonomous character of morality.

In his opinion, the manner in which we should act is not determined by any externally established system, but by deduction and rationalism, which is not limited only to our activity in the cognitive sphere. Hobbes stresses that we are not guided by reason only when we engage in science or philosophising and psychologising. As he writes: "We can also use an a priori proof in politics and ethics: in knowledge about what is just and unjust, rightful and wrongful, because we ourselves have created the principles of recognising what is just and right and, on the contrary, what is unjust and wrongful (...)." (see Hobbes, 1956: 404). Therefore, the source of axiology lies in ourselves and it is the human perspective that decides on the moral construct of the individual. Good is what we regard as good, so it is difficult to talk about values in the intersubjective dimension. It is a question of moral autonomy of each human being, which is based on the belief refusing the privilege of axionormative law-making ${ }^{5}$ to the exterior or God.

${ }^{4}$ Here I mean egoism in the interpretation of Friedrich Nietzsche, i.e., the "law of perspective applied to feelings: what is the closest, appears large and weighty, and as one moves farther away, size and weight decrease" (Nietzsche, 2008: 153).

5 The resignation from the theological justification of morality is illustrated by Kant's famous saying: "The starry sky above me and the moral law within me." It must be noted, however, that, in contrast to Hobbes, Kant deeply believes in the good will of the human being for whom the fulfilment of his own humanity is the foundation of his ethical system. Kant's categorical imperative says very clearly: "Act in such a way that you treat humanity, whether in your own person or in the person of any other, never merely as a means to an end, but always at the same time as an end." How could we understand these works? I think that Kant means the effect of essentially humanistic imitation to which we should incline others through our decisions and behaviours. By doing good, we fulfil our humanity and the moral vocation proper to it. On the other hand, when we act unfairly, we do harm and entitle others to do it. 
A consequence of such personalisation can be the legalisation of egoism, which becomes represented by a manifestation of ethical freedom and independence, as well as the emblematic situation of choosing between the one whose good is more important. ${ }^{6}$

\section{The theory of agonism}

Being an enemy is a true friendship. William Blake, The Marriage of Heaven and Hell

In this context, the problem of democracy, which becomes reduced to dialectical thinking or, as it might be more appropriate to say, agonistic thinking, appears to be very significant (see Mouffe, 2015). Its foundation is the very Nietzschean and Weberian belief that pluralism functioning in democracy cannot reconcile all points of view. Thus, assuming this type of statement, we should also agree that antagonism is unavoidable. Moreover, it is a kind of negativity or "politicality" (see Mouffe, 2005) that is an inseparable element of pluralism itself.

Unfortunately, this fact is ignored by the liberal theory making use of utopianism that suggests, for example, that ultimate and full reconciliation is not possible. The adoption of this perspective is dangerous because liberalism actually strengthens differences instead of removing them. Moreover, it forms an essential antagonism between equality and plurality. Therefore, its irremovability must re-

\footnotetext{
${ }^{6}$ Referring to Hobbes in my text, I highlight, among others, the material aspect of egoism and conclude that "having the possibility of fulfilling his own good before others" good, the human being makes use of his environment in order to satisfy his interests and materialise his ambitions. The inclination to harm others, which is a consequence of egocentrisms, explains the need for the existence of an ethical system that would regulate interpersonal relations between most citizens. However, this approval would be conditional upon the fact that it could not force us to resign from our own needs the fulfilment of which is a priority and which do not have to remain opposed to the interest of the community. Thus, the aim is to find the grounds of agreement between the individual and society and, as a consequence of this, to determine certain rules of conduct that, by stopping individual drives and egoisms, would negate the appropriation of someone else's property and the violation of personal rights. Such a system is guaranteed by the Rawlsian idea of public reason and strong democracy that, by allowing - in an indirect manner, as it would be naive to assume that the direct fulfilment of this postulate is possible in the age of postmodern societies - most citizens to speak, would enable them to verbalise their expectations and then to formalise them [this means "obedience to the law that one has prescribed to oneself," or freedom within the meaning defined by Jean Jacques Rousseau]. This would result in the creation of certain norms or, as Hobbes would say, instructions telling us how to make use of freedom. This is because each freedom is limited. The borders of my freedom reach as far as they do not violate others' freedom" (Jastrząb, 2014: 56).
} 
sult in the abandonment of the idealistic vision by democracy. A society devoid of contrasts can be evaluated only in terms of collective imagination. It is a surrealistic ideal that simply cannot be achieved.

Here, it is worth noting that rationalism and individualism accompanying such liberal faith also contradicts something that is particularly significant in the context of nationalism. In liberalism, it is difficult to capture the essence of political identity, which always has a collective - and, therefore, also supraindividual dimension irrespective of its ideological character. Thus, in order to discover what really is behind the given identity and how it can be opposed if necessary, we must recognise and understand various kinds of actions and affective mechanisms. However, we cannot do so if we subordinate the community to the past, at the same time believing very axiomatically in the postmodernist cult of individuality released from the oppressive grip of the community.

The starting point for such opposition should be the assumption of the insolubility of some conflicts. ${ }^{7}$ As a consequence of this, we would have to admit, just as Carl Schmitt wanted, that there is no rational end for some disputes. They last and antagonise people almost continuously, which should incline us to think about them in terms of traditional dialectics Us (friend)/Them (enemy) or to treat them as a relation confronting two oppositions with each other. The second solution is particularly good because it allows us to recognise the legitimacy of postulates represented by the opposite party. This is, therefore, not a case characterising relevant antagonism, but rather agonism that manifests itself not only in the mutual awareness of insolubility of the conflict, but also the acceptance of a set of norms regulating this conflict. Chantal Mouffe confirms this fact when writing that "there is some kind of conflict consensus between opponents - they agree as to the ethical and political rules organising their political organisation, but they interpret them in a different way." (see Mouffe, 2015: 141). Thus, this consensus is favourable for democracy itself, because it constitutes a base for pluralism that does not submit to blind negations. ${ }^{8}$ This, in turn, results in the possibility of co-existence of such dialectic forces that would be able to abolish the hegemonic order valid in the given context.

7 Therefore, antagonism would have to be perceived as a specific form of existence of society. In view of this, there is no way of overcoming or explaining the conflict. We cannot do this even by fulfilling the ideals of Marxist revolution, which seeks sources of antagonism in social inequalities and hostility resulting from this.

It is also worth noticing that these are not only economic conflicts. They may result, for example, from ideological differences, different visions of national axiology, or religion.

${ }^{8}$ Overcoming such negation is possible through the agonistic recognition of "passions", i.e., emotions and desires constituting collective identity. 
Hegemony is a key concept here, because the architecture of interpersonal relations is specified by hegemonic practices being the real "articulation of the relation of power". Thus, we always deal with the social order that is political, because its alternative visions of "being" are excluded by the domination of the hegemon. The hegemon's position, however, is not something constant. It is rather a fluid construct resulting from specific power relations. Thus, the change is possible, but the prerequisite for its existence and the resulting transformation is hegemonic reconfiguration. A consequence of the belief that such reconfiguration is feasible at all must be resignation from dogmatism, the symbol of which is the idea of natural order, which is original to some extent, rather unchangeable and certainly irreplaceable. This excludes stability in favour of constantly possible transformation. The theory of hegemony clearly indicates that the materialisation of the alternative order is the question of a relevant counter-hegemonic strategy, i.e., relevant practices being a form of interference or intervention in the field of existing reality. Thus, the change has a hegemonic character, because displaced hegemony is replaced, irrespective of circumstances, with a slightly different kind of hegemony that is more effective in political struggle.

A logical implication for the post-Marxist conception outlined here should be certainly the awareness of confrontational permanency. It negates hope for the creation of ideal democracy and the vision of achieving a state in which there will be no antagonistic tensions is perceived by it in terms of romantic and revolutionary naivety. It is, therefore, easy to notice that compromise and something that Chantal Mouffe and Ernesto Laclau call the "chain of equivalence." (see Laclau, Mouffe, 2007) become particularly important in this context. How should this term be understood? It is a kind of agreement and frequently also a program community that connects representatives of interest groups, often being very different. ${ }^{9}$ The foundation of their "contract" is the respect for mutual expectations, requests and postulates and striving for the establishment of a new, implicitly more humane, hegemony. ${ }^{10}$ The achievement of this common goal is conditional upon turning

9 For Mouffe, an example of such chain of equivalence is an anti-hegemonic coalition combining emancipation movements with the working-class movement; "according to us, the challenge for the left wing was to discover such manner of articulating new demands put forward by feminists, anti-racists, gay and ecological movements that these demands could be combined with those formulated in class categories" (Mouffe, 2015: 136).

${ }^{10}$ One could risk the statement that hegemonic rivalry slightly resembles at some level what Peter Sloterdijk called the secularised version of the idea of Last Judgement: political movements assume a form of "anger banks" that accumulate social bitterness and strive for the establishment of a new order. What they have in common, is a promise of joint revenge and a vision of better and fairer reality. However, when the postulated order cannot be achieved, "a desire for another revolu- 
"democratic fights" in such a direction that the broadest possible collective will would be created. Only then will it be possible to radicalise democracy that will truly follow its values. As Mouffe indicates, "the problem of modern democratic societies does not lie in ethical-political rules of freedom and equality, but in the fact that these rules are not put into practice" (see Mouffe 2015: 137). In order to change this, it seems necessary to organise diversity in such a way that it would be possible to establish unity on the part of all progressive and pro-democratic forces having an anti-hegemonic potential.

It is, however, worth remembering that it should be a unity working on the basis of the traditional division marking the borders of leftist and rightist thought. After all, the adverse model of policy is of key importance for the functioning of agonistic democracy. ${ }^{11}$ It is impossible to fulfil its relevant practices by abandoning the constitutive distinction for the insolubility of some social conflicts. Although we have observed rather the processual departure from the dialectic discussed here in the last few years, it is possible to reverse this tendency and to strengthen the pre-evolution state that will put an end to the blurring of ideological borders. The followers of agonism prove - rightly, in my opinion - that the political inclination to be in the "centre" excludes the potentiality of carrying out a real change. The only condition for abolishing the hegemonic order and carrying out the resulting reconfiguration or revision-based transformation is an alternative existing on the part of the opposition.

There is yet another problem resulting from this. The lack of the postulated division results in intellectual laziness and non-engagement in political life among citizens. And limited participation contradicts the idea of democratisation of democracy itself (see Górski, 2007). It creates a climate that is not favourable for political empowerment and hinders the performance of grass-roots participatory actions. People do not engage because they lack the sense of authentic perpetration and believe that things in which they believe and which follow actually do not count. Thus, they live in an illusion that the choice - even if possible - is only apparent. They think that true alternatives are unavailable. Hence the growing support for the radical right wing, which creates an illusion of alternativeness by using xenophobic and pseudopatriotic demagogy. The anti-hegemonicality offered

tion arises: a true, total revolution that will satisfy the disillusioned and perform emancipation work." Žižek, 2012: 148-149.

${ }_{11}$ As we can see, agonistic democracy remains opposed to the vision of the post-political world, i.e., the conception of "cosmopolitan second modernity". Its authors (Ulrich Beck and Anthony Giddens) postulate a manner of political thinking that will go beyond the dialectic division that they consider to be archaic (the left wing vs. the right wing). 
by them objectivises the surrounding reality once again. Also because of it, the privilege of shaping symbolic hierarchies, i.e., the valuation and the assignment of senses and interpretations, rests with the group that has been marginalised so far as destructive and unacceptable to the civilised majority. This leads to the degradation, or even the total negation of the needs of each minority and sometimes even majority, because it is very easy to qualify for a group of representatives of hostile non-prescriptiveness. In the macrostructural scale, the benefits of the European integration are put in question. The support for the increasingly uniting European Union is replaced with Euroscepticism, which is a sign of supranational (transborder) mistrust and fear of strange and unrecognised things. Therefore, the threat of radicalism has both internal and external implications that are connected with relationality in the global dimension.

The awareness of what I am writing here about is particularly important because the resignation from the dialectic between the left wing and the right wing is almost always accompanied by the establishment of a new opposition that is, unfortunately, much more abstract. Its essence is the use of the axiological opposition of good and evil. It is actually the practice of moralisation of politicality, which can be explained by the deficit of identifications embedded in political tradition. The impossibility of finding the proper representation that would meet the social expectations of collective political identity results in an identification void that is taken over very skilfully and efficiently, on the one hand, by the fraction of the Church led by Tadeusz Rydzyk and, on the other hand, by extremely populistic and nationalistic parties. The representatives of both of these groups are connected not only by conservatism and hostility towards otherness in its broad sense, but also the similar and rather hermetic definition of the community. They are also characterised by a separate identity that satisfies the needs of safety and belonging, which are fundamental from the perspective of an individual. The added value that accompanies this is something that Nietzsche called the "herd instinct" in The Gay Science. It means the morality that derives not from ourselves, but from the community to which each of us belongs (see Nietzsche, 2008: 174). Writing about this, Nietzsche stresses that "wherever we encounter a morality, we also encounter valuations and an order of rank of human impulses and actions. These valuations and orders of rank are always expressions of the needs of a community and herd: whatever benefits it most - and second most, and third most - that is also considered the first standard for the value of all individuals." Thus, according to Nietzsche's interpretation, morality is actually a herd instinct that, being always subordinated to a larger community, determines the axiological construction of the entity. Obviously, there is no exclusive morality, as there is no exclusive group, 
state and society. In view of this, we must conclude that the multitude of possible ethicalities increases the likelihood of antagonistic struggle and confirms its irremovable presence in the sphere of social and political life.

In this context, it is worth noticing how important group forms of identification are to us. But do all collective identities meet the conditions of agonism? By no means, and the best proof of this is the fact that the aforementioned entities do not create a space for the functioning of an agonistic debate. It is, therefore, necessary to make such a distinction in agonism that would make it possible to carry on such debate while maintaining the dialectical division Us/Them as an immanent element of democracy. However, in order for this attempt to be successful, the excluding and very subjectivised moral register must be abandoned. It is known from experience that, after all, extreme Catholic radicalism and "fascist" extremism cannot be fought with the use of arguments perceived in ethical rather than political categories. Finally, it must be stated that an agonistic debate is acceptable only when we are dealing with opponents, not with enemies who are stigmatised by a negative moral definition. When facing enemies, we are unable to talk and unable to argue. There is no common ground between us, because what determines our mutual relation is the will to eliminate what is hostile: in addition, this will does not take rational thought into consideration and is profoundly dogmatic. ${ }^{12}$

It must be stressed that agonistic democracy is a project that should not be perceived as an alternative to liberal democracy. It is rather a kind of internal ideological opposition, but an opposition being still a part of the liberal context. As Francis Fukuyama aptly notices, "what we cannot imagine, is a world that would significantly differ from ours, at the same time being more perfect" (see Fukuyama, 1997: 81). Thus, the theory of agonism is only one of many possible answers to the dispute concerning the shape of the society that essentially does not resemble Fukuyama's ideal. In view of this, thinking about the "end of the history" is not only a mistake, but also a sign of ignorance and intellectual apathy: the factors with which we should associate the homo sovieticus attitude that characterises Poles so strongly.

Any change resulting from participation in power or fight for this power requires free awareness to which being will be subordinated, not the being that will determine this awareness (see Tischner, 2005: 145). This naturally does not contradict the need for group identification. The only important thing is to think,

${ }^{12}$ In the introduction to the book on the current interpretation of Carl Schmitt's thought edited by herself, Mouffe writes about this as follows: "The opponent is an enemy to some extent, but an acknowledged enemy with whom it is possible to find common ground. Opponents fight against each other, but they do not question the legitimacy of their positions" (Mouffe, 2011). 
"be" (to use Martin Heidegger's terminology) and assume responsibility for this "being". After all, it is better to function as a subject than as an object of the only correct and irremovable authority. Enslavement resulting from passivity not only excludes the existence of anti-hegemony, but also makes critical reconfiguration a constitutive element of agonistic democracy - impossible. On the other hand, a change of the prevailing social order is something that can and very much must be carried out. However, the rearrangement of this order must be conditioned by the acceptance of fight and antagonism which assumes and explains the fluidity of the status quo, which is actually imagined rather than real. This is because phantasmatic and universal stability is replaced with an "empty signifier" awaiting new contents. This happens because the understanding of things, including those that we regard as rightful and wrongful, is a question of imposition, questioning and reinterpretation deriving from the hegemonic relation of power, which is labile par excellence, as it still faces the risk of being superseded.

Thus, what does agonistic democracy head towards? It seems to be an intellectual conception which regards the disclosure of what is not fully brought to public attention as the foundation of its assumptions and the raison detre of its policy as such. The aim is to give a political form to the state of conflict that always accompanies us in social life and, consequently, to civilise antagonism as such: the moment that Jean-François Lyotard calls "setting at variance." ${ }^{13}$ It is supposed to be a kind of contentious negativity that, allowing for the multitude of view and the variety of visions, will be aimed at reaching a conflictual consensus. Being interpreted in such a way, democratisation that combines the features of agonistic democracy and radical democracy will increase a chance for strengthening pluralism and enlarge the emancipational range of possibilities. It will also break with Marxist tradition that defined public and private reality through references to economism without noticing completely different contexts related to culture and history.

It is worth stopping for a moment to describe the identity of the subject according to Ernest Laclau's interpretation. The dominant and actually the only decisive criterion determining the shape of political identity in Marxism was economic conditions. The access to means of production determined who we were and what choices we made. Today we know that this perspective is rather ineligible and not fully empowered in the complicated and complex reality. This is because collective identity has a post-structural and discursive character. As something that "comes into being", it constitutes a construct resulting from social relations and the com-

13 The essence of a conflict is not a clash between enemies, but a confrontation between opponents. In this way, antagonism is replaced with much less radical agonism. 
munity of unfulfilled demands. ${ }^{14}$ It is a being opposed to the subject of authority, whose hegemony makes it impossible to fulfil something that is of key importance for the identification of the given political identity. This "something", as I have already written, is the foundation of the chain of equivalence, i.e., "being together" in spite of diversity and particularity; although political identity is bonded by the element that is acceptable to and representative of all of its members, there is no homogeneousness here. ${ }^{15}$ The source of common identification is an "empty signifier" that is devoid of a single ontic reference. It determines subjectiveness while avoiding enclosure within the frames of full conceptual representation. ${ }^{16}$ This type of "wholeness" is actually a "partial object" towards which a collective consensus has occurred. In other words, it is a type of investment that determines the political direction of the narrow economics of attempts. Only such assigned "sense" creates a chance for the emergence of a new identity and, in the long term, the establishment of a new hegemony capable of solving real problems.

The natural conclusion arising from what Mouffe and Laclau wrote about must refer to the inability of society that would be subordinated only to one narration. The universality of this narration is an idealistic illusion and a harmful phantasm worthy of negation. Society can never be uniform, because it is a game of differences and relations to others. Therefore, it should not be perceived as a closed whole, but rather as a sum of antagonisms and a structure that is a result of the "discursive-political configuration of elements."

The society perceived as a whole is a fiction in the sense that it depends on a multitude of senses that a single political discourse (discursive formation) cannot embrace. This problem can be solved only by the "practice of bonding," ${ }^{8}$ or the strategy of integrating individual "isolated" elements under the influence of the

${ }^{14}$ Thus, the collective subject is the subject of demand, just as the individual subject is the subject of desire. We can find here a direct reference to Jacques Lacan, whose psychoanalysis postulated the perception of subjectiveness through the prism of the "lack" being felt or experienced (the rapture of the bond with the mother). For more about this, refer to Ernest Laclau's book On Populist Reason.

${ }^{15}$ A similar assumption is made by Slavoy Žižek, who notices that "critical mass" "can form only as a result of the equation of various demands; (...) that revolution occurs not only when various antagonisms merge into one great Antagonism, but when they interact between one another" - Žižek, 2012: 150 .

${ }^{16}$ Laclau even writes about the "irremovable inability" of such conceptual representation.

${ }^{17}$ Here I refer to the political theory of discourse that, contrary to what Michel Foucault thought, comprises not only language-related discursive practices, but also all kinds of social mechanisms and actions. There is actually no division into what is discursive and non-discursive, because all senses are constructed as part of a discourse.

${ }_{18}$ The idea of "bonding" has been described very well by Antonio Gramsci and used in their conception by Mouffe and Laclau. For them, the practice of bonding is the practice of articulation 
hegemonic dominant feature, i.e., the nodal point serving as a common reference. Unfortunately, "embracing" all elements situated in the field of discursiveness is completely impossible in practice. This must bring forth a kind of opposition and subversiveness assuming a form of another (always hegemonic) political discourse or a structure that Mouffe and Laclau call the discursive "outside". What does this "outside" mean? It is a set of all those semantic elements that could not be included within the frames of the given formation. Excluded and devoid of the stabilising bond, they consequently pose a threat to the discourse, which should fear every destructive potential.

Talking about the discursive formation itself, it is difficult to identify the most privileged one. In Marxism, it was the working class; today there is no way of proving that it fulfils any special role in the process of hegemonic change. Therefore, it cannot be ascertained which discourse is the most important, because its "measure" is determined by the context in which it is placed and the goal that it tries to achieve. Another key aspect in this case is the entire range of connections and the nodal point that serves as an axis of reference for dominated antagonisms. The most attractive thing is, of course, this nodal point, which can ensure the broadest possible structure of the chain of equivalences, i.e., all entities being a constituent part of the new hegemonic power.

\section{Agonistic democracy vs. deliberative democracy}

Taking the topic of my reflections into consideration, I must stress that I am interested in the theory of hegemony and the theory of discourse mainly due to their political and cultural dimension. Within this scope, two assumptions are of key importance for me. The first one says that senses are formed by hegemony and the discourse related to it, which imposes not only the interpretation of social practices as such, but of reality as a whole. ${ }^{19}$ The second one proves double irremovability. This is because both antagonism itself and the semantic conflict that always accompanies it and is manifested by the ideological opposedness of Poles are equally permanent. ${ }^{20}$ We understand in different ways, because discourses being our rep-

leading to the formation of a new discourse. The discourse itself, in their opinion, is a sort of a structured whole: a "system of differential entities - that is, of moments" (Laclau, Mouffe, 2007).

19 According to Laclau, the discourse is the area that determines the shape of objectivity.

20 Tomasz Sawczuk confirms this in his commentary to the election of Andrzej Duda to the office of Polish president. In his text, he stresses, among others, that the "in present-day conditions, policy of love [postulated by the current President and today limited at least to the symbolic sphere] 
resentation are different. Thus, some people may identify with the emancipational discourse, whereas others may identify with the conservative-Catholic discourse. However, not only our ideological orientation, but also the position determining the character of our internal life and our attitude to otherness will depend on what structure we will refer to As we can see, the genealogy of antagonism has a discursive dimension because the difference being the source of a conflict manifesting itself in the opposedness of "subjective positions" lies in the discourse and the identity of the sense that it constitutes. ${ }^{21}$ It must be remembered that the subjective position is never ultimately closed, because it is also a discursive position, which tends to have an open dimension because it depends on other subjective positions. This must result in the similarly relational character of a being.

Besides, it is worth saying that this relationality contains what is the most important to me. Referring to Hegel, Moufe and Laclau prove that it is impossible to speak of a being by defining it in terms of positive identity. After all, the essence of such identity is stability and hermeticality that contradicts everything that is connected with relationality as such. Therefore, a being must be a negative identity, because it is never such a closed structure, and this is proved best by the fact that its constitution is always conditional upon the attitude to an outside being, which means - referring again to the figure that I have used above - the Other fulfilling the role of an excluded element. ${ }^{22}$ The reason for which it is excluded must be explained by the statement that, functioning as if outside the discursive connection of the specific group, it forms an archetype of unapplied otherness. ${ }^{23}$

cannot be based on the fact that everyone will focus on adoring something abstract and external, which gives sense to their collective life, regardless of whether it will be God, money or Polishness. Focusing around tribal totems in politics favours primarily the fraction choosing totems and results in the exclusion of people who do not share our faith, profess other religions or are less fervent believers; and, after all, irrespective of any central difference, we could manage to reach agreement with them." Such an attitude could be perceived as a praise of agonism, which emphasises the pluralistic dimension of politicality while admitting the possibility of a consensus transcending divisions, but not taking everyone into consideration (Sawczuk, 2015).

${ }^{21}$ They constitute a kind of visual representation relevant to the given being.

${ }^{22}$ We can speak here of the logic of equivalence, which manifests itself in the dialetical division into "insiders" and "outsiders". It was easiest to observe such a division even a relatively short time ago, when we dealt with the juxtaposition of the broadly understood opposition movement, or the "nation", with the regime of the People's Republic of Poland. At that time, the nodal point was the anti-system attitude, which allowed people to determine their own identity in contrast to the authorities. Such a chain of equivalences referred to resistance and consisted of a very large number of subjective position, which determined the strength of the chain and the chance for abolishing hegemony.

${ }^{23}$ In Poland, such an archetype of otherness is the Jew, towards whom other kinds of otherness are also created, including the feminine otherness closed in the figure of a witch, which is excellently 
The structural effect of full and ultimate "stitching" of signifiers is, therefore, impossible, which must subvert the vision of society as a whole, because a being under constitution requires a reverse, i.e., the opposition resulting from otherness that not only remains in contrast to the identity under construction, but is also a processual condition for the construction process itself. In this sense, the Other is an external being, a "body" determining the borders of the discourse and society, which is reflected by its symbolic (semantic) character. On the other hand, irremovability and the impossibility to include the Other in the community is an evidence of antagonism, which only confirms the permanent dimension of the conflict. It is worth noticing in this context that a consequence of the exclusion related to the above is the emergence of even more exclusive and closed homogeneousness. ${ }^{24}$ After all, the results of psychoanalytic and ethnographic studies prove that the lack of the other must go hand in hand with the search for an internal enemy, which leads at a certain level to a destructive paranoia that reflects antagonism rather than essentially "broad" agonism. Therefore, the deconstructionistic criticism of liberal imagination proclaiming the possibility of full reconciliation in its most optimistic and idealistic form is inscribed in the theory of agonism. This, however, results not only in the appreciation of hegemony and difference, but also in the belief that the realised absence of "fullness" undermines the sense of deliberation, questioning de facto the essence of deliberative democracy itself in the way in which it was understood by Jürgen Habermas.

This is because the recognition of the ontological dimension of "radical negativeness" questions rationalism, which is so important for Habermas. If this statement may appear groundless, it is necessary to recall Habermas's fundamental assumption that the hope of democracy lies in the rationality of communication. The German philosopher believes we cannot save our valuable ideals without performing the practice of social interaction. The latter should be based on the development of "action plans". Each of such plans would actually be the result of engagement of the group whose views and preferences assuming the form of an argumentative game should support the mandate of institutional entities. Such form of participation would, in turn, result in superseding dysfunctional and conflict-prone emotional-instrumental rationality. In other words, an intellectual base for the deliberative model is the belief that the confrontation of arguments and

described by Professor Joanna Tokarska-Bakir in her essay Ganz Andere? The Jew as a witch and the witch as a Jew [Ganz Andere? Żyd jako czarownica i czarownica jako Żyd].

${ }^{24}$ This is particularly visible in Poland, which has been an incredibly homogeneous country since the end of World War II. If the use of this euphemism is justified here at all, we must say that it is mainly the result of the "disappearance" of Jews. 
counterarguments being fulfilled in the course of social interaction may lead to a consensus that would satisfy everyone. ${ }^{25}$ Thus, consensuality would have an intersubjective dimension, because it would derive not from manipulation or paternalistic authoritarianism, but from persuasion and conversation expressing the ability to conduct discourses. ${ }^{26}$ It can, therefore, be clearly seen that deliberative democracy significantly differs from agonistic democracy, which abandons the search for a consensus and acknowledges the permanence of antagonism and the necessity of hegemonic rivalry. ${ }^{27}$

Thus, it is necessary to answer the question regarding the possibility of occurrence of Habermas's democracy in Polish conditions. It is difficult to imagine that admitting virtually everyone to the space of a debate would be justified and desirable. Besides, it seems to be a universal problem that is not limited to the Polish context only. The key issue here is, therefore, inclusion that should be selective, because, as Jan Józef Lipski aptly noted: "dialogue is not always possible" and, moreover, "the very attempt to establish a dialogue is often a disgrace (if not sheer folly)" (see Lipski, 2011: 149).

Of course, there are some more dilemmas connected with deliberative democracy. ${ }^{28}$ The one concerning subjective acceptability is particularly important to me: mainly because it allows for the constantly existing likelihood of occurrence of an antagonism that cannot be reconciled with democracy. Thus, Mouffe and Laclau are right when postulating a completely different approach devoid of liberal naive-

${ }^{25}$ Hannah Arendt reaches a similar conclusion. In her opinion, however, a consensus can be reached not thanks to the rational Diskurs, as Habermas would want, but thanks to an exchange of opinions and votes. Therefore, the difference between them lies in the fact that "according to Habermas, the consensus arises with the participation of what Kant calls disputieren - an exchange of arguments limited by the rules of logic, whereas for Arendt it is a question of streiten, in which an argument is created through persuasion, not through irrefutable proofs" (Mouffe, 2015: 25).

${ }^{26}$ Thinking about communication, Habermas specified the role of language very clearly. He said, among others, that it is "relevant to a communicative action only in the pragmatic aspect; the speakers, using sentences in a manner aimed at reaching a consensus, refer to the worlds not only directly - as in a teleological action guided by norms and a dramaturgical action - but in a reflective manner" (Habermas, 1999: 186).

${ }^{27}$ As in the case of Mouffe and Laclau, the deliberative approach is not accepted by the French philosopher Bernard-Henri Lévy, who writes in a letter to Michel Houellebecq: "But the truth is, I don't believe in it [dialogue] and in real life I've never understood the theory according to which it is enough to oppose each other, confront arguments and counterarguments, for the shadows of ignorance to lift as if by magic. People begin most discussions by contributing their own beliefs and conclude them with the same. The idea of dialectics that would allow them to refine their point of view, to enrich or change it, has always struck me as highly" (Lévy, Houellebecq, 2012: 315).

${ }_{28}$ This issue is covered more extensively by John Dryzek in his book Deliberative democracy and beyond, and by Adam Romaniuk in an article published in Kultura Liberalna: O Habermasie i troche o polskiej polityce [About Habermas and a few words about Polish politics]. 
ty. In their interpretation, there is no universality; there is hegemony that replaces this universality. For advocates of the theory of agonism, constantly multiplying particularisms are a potential source of what can be called the representation of the common moment. When they acquire the status of dominating hegemony, they can become a symbol of full "stitching", or a substitute for so intensively sought-after but phantasmatic "fullness" that is actually only an ideological motor of the emancipational effort. This effort is still necessary, because hegemony is not stable. Its temporariness is the fact that must determine the fluidity of rivalry. ${ }^{29}$

The aim of the agonistic fight is the aforementioned empty signifiers, i.e., "a signifying element without a signified element". In other words, is it a representation of absence anticipating hegemony, a specific substitute for what is absent and impossible. This is the stake of the aforementioned rivalry, which also has its psychoanalytic dimension. Just like Mouffe, Laclau highlights the affective aspect of politic (see Laclau, 2009). Finding theoretical support in conceptions by Sigmund Freud and Jacques Lacan, the Argentinian author proves that the affect - an emotionally burdened "partial object" - is a very important point creating the group bond. It acts as a binder that connects individual discourses into a hegemony being a symbol of "fullness." ${ }^{30}$ Although achieving such fullness is naturally impossible, it seems possible to achieve the effect of group will that could change the identity of groups in such a way that it would be possible to articulate interests and demands of broadly understood social "diversity". Thus, democracy - in its agonistic and radical rather than deliberative form - should be conceived not as a goal, but a means to achieve the goal of pluralism.

\section{Bibliography}

Czarnecki P. (2011), Historia filozofii, Warszawa.

Deleuze G. (2012), Nietzsche i filozofia, przeł. B. Banasiak, Łódź.

Fukuyama F. (1997), Koniec historii, trans. T. Bieroń, M. Wichrowski, Poznań.

Gellner E. (2009), Narody i nacjonalizm, trans. T. Hołówka, Warszawa.

Górski R. (2007), Bez państwa. Demokracja uczestnicząca w działaniu, Kraków.

${ }^{29}$ In his essay Universalism, Particularism, and the Question of Identity Laclau states: "If democracy is possible, this happens because the universal has no necessary body and no necessary content; however, various groups compete with one another so that their particularisms would perform the function of universal representation." (Laclau, 2004: 66).

${ }^{30}$ An example of such affective binder in Laclau's spirit was certainly the Polish Solidarity. The phenomenon related to the latter would, therefore, have to be regarded as a symbol of "fullness" of society that can never be achieved. 
Habermas J. (1999), Racjonalność działania a racjonalność społeczna, trans. A.M. Kaniowski, Warszawa. Havel V. (2011), Siła bezsilnych $i$ inne eseje, Warszawa.

Hobbes T. (1956), Elementy filozofii, vol. 1, trans. Cz. Znamierowski, Warszawa.

Houellebecq M., Lévy B.H. (2012), Wrogowie publiczni, transl. M.J. Mosakowski, Warszawa.

Jastrząb P. (2014), Orientacje antyneoliberalne młodzieży partycypującej w globalnej rzeczywistości cywilizowanego przypisania do ryzyka, maszynopis pracy magisterskiej, Poznań.

Jastrząb P. (2015), Polityczność sztuki wobec agonizmu, maszynopis pracy magisterskiej, Poznań.

Kołakowski L. (2015), Ludzie są dobrzy, Kanon nr 1, Tygodnik Powszechny, Kraków 22.04.

Laclau E. (2004), Emancypacje, trans. L. Koczanowicz, Wrocław.

Laclau E. (2009), Rozum populistyczny, trans. T. Szkudlarek, Wrocław.

Laclau E., Mouffe Ch. (2007), Hegemonia i strategia socjalistyczna. Przyczynek do projektu radykalnej polityki demokratycznej, trans. S. Królak, Wrocław.

Lipski J.J. (1992), Tunika Nessosa: szkice o literaturze i o nacjonalizmie, Warszawa.

Lipski J.J. (2011), Pisma polityczne, Warszawa.

Mouffe Ch. (2005), Paradoks demokracji, trans. W. Jach, M. Kamińska, A. Orzechowski, Wrocław.

Mouffe Ch. (2011), Carl Schmitt - wyzwanie polityczności, trans. T. Leśniak, Warszawa.

Mouffe Ch. (2015), Agonistyka. Polityczne myślenie o świecie, trans. B. Szelewa, Warszawa.

Nietzsche F. (2008), Radosna wiedza, trans. M. Łukasiewicz, Gdańsk.

Pomian K. (2004), Europa i jej narody, trans. M. Szpakowska, Gdańsk.

Sawczuk T. (2015), Dudapeszt, miasto miłości, https://kulturaliberalna.pl/2015/08/11/andrzej-duda-prezydent-tomasz-sawczuk/?fb_comment_id=821681754612363_823773501069855, accessed: 24.02.2019.

Tischner J. (2005), Etyka solidarności oraz Homo sovieticus, Kraków.

Tokarska-Bakir J. (2001), Ganz Andere? Żyd jako czarownica i czarownica jako Żyd, Warszawa.

Tokarska-Bakir J. (2014), Rozum w Polsce wysiada, [an interview to K. Leśniewicz], Przegląd no 34 (764), pp. 8-13.

Wielgosz P. (ed.) (2012), Co dalej z demokracją?, trans. M. Kowalska, Warszawa.

Wójcicki Ł. (2015), Logika polskiego chrystianizmu, http://wojcicki.codziennikfeministyczny. pl/2015/09/06/logika-polskiego-chrystianizmu/, accessed: 24.02.2019.

Žižek S. (2012), Między demokracją a boską przemocą, [in:] P. Wielgosz (ed.), Co dalej z demokracją?, Warszawa. 
